\title{
The Effect of Storage Container and Light Exposure on Biodiesel Characteristics Derived by Crude Palm Oil
}

\author{
Amir Khalid ${ }^{1, a}$, B. Manshoor ${ }^{1, b}$, Azwan Sapit ${ }^{1}$, Mohd Azahari Razali ${ }^{1}$, \\ I. Zaman ${ }^{2}$, M.D. Anuar ${ }^{1}$ \\ ${ }^{1}$ Combustion Research Group (CRG), Centre for Energy and Industrial Environment Studies \\ (CEIES), Universiti Tun Hussein Onn Malaysia, Parit Raja, Batu Pahat, 86400 Johor, Malaysia \\ ${ }^{2}$ Universiti Tun Hussein Onn Malaysia, Parit Raja, Batu Pahat, 86400 Johor, Malaysia. \\ aamirk@uthm.edu.my, bukhari@uthm.edu.my
}

\begin{abstract}
Keywords: Biodiesel, Storage Duration, Biodiesel Characteristics, Mixture Formation, Optical Visualization
\end{abstract}

\begin{abstract}
This study investigated the effect of types of storage container used to store biodiesel blend (B5) under different storage duration and environment. The biodiesel samples were stored in plastic and glass container under indoor condition with exposure to fluorescent light for 12 weeks. These samples were monitored and the properties tests were recorded for weekly basis. The effects of storage conditions on properties of biodiesel, experimental testing on density, viscosity, acid value, water content and flash point were discussed in detail. Analysis of this study showed that different storage duration, condition and container used gave a significant effect toward the changes of water content, acid value and viscosity. Sample stored in a glass container under indoor without being exposed to any form of light condition recorded the best quality while sample stored in a plastic container under outdoor condition had the worst quality. A long period of storage would decrease the quality of biodiesel due to exposure to direct sunlight, oxidization between ambient oxygen and double bond biodiesel, hydrolysis process between the ambient air and methyl ester and condensation within the storage tank.
\end{abstract}

\section{Introduction}

In recent years, alternative fuels, energy efficiency, environmental protection, energy conservation and management have become important due to depletion of fossil fuel and environmental degradation. The alternative fuels or so called biodiesels can be better tried for diesel engine as compared to petrol engines because of the construction of the diesel engine is very robust and can work under high compression ratio along with a significant amount of excess air. Biodiesel fuel will mix with air in the combustion chamber to go through compression ignition [1-2]. After the ignition process, performance and emission are produced. In this study, focus would be on Storage and handling of biodiesel fuels whereby storage and handling are significant factors which can influence the quality of biodiesel as it is prone towards degradation as compared to fossil fuel. Normally, fuel is stored in a large vessel or tank at outdoor places so it is exposed to natural environment condition where the properties would change according to weather [3-4]. The factors which could accelerate the degradation of biodiesel include air (oxygen), light (UV), elevated temperatures, trace of metal, peroxide and the surface area between biodiesel and air. Biodiesel fuel is more hygroscopic compared to diesel fuel. It has a natural tendency to absorb moisture and water which tend to condense on the metal surface, favoring the corrosion [5-7]. Even though the exposure of biodiesel towards light and air are reduced to the minimum level, but after sometime, traces of air and light will still slip through and come in contact with the biodiesel inside. To make thing worse, heat from surrounding, presence of metals and water in the fuel may even speed up the oxidation process. Besides, contamination by bacteria or fungi might result in the biodegradation of biodiesel and blends. According to the requirement of international quality standard specifications, if the biodiesel is produced by crude palm oil (CPO), the level of free fatty acid and moisture content in CPO are the prime quality that should be measured. The quality of crude palm oil is largely determined by all sorts of factors such as from the nature of the parent tree, post-harvest handling, and error occurred during processing, transportation and storage technique [8-10]. In this study, the properties of the 
biodiesel blend (B5) in relation with its storage time was tested and determined in weekly basis in terms of density, viscosity, acid value, moisture content and flash point. These values and data were tested for 8 weeks duration to represent the biodiesel blend (B5) properties against different storage time. The sample of biodiesel was taken from UTHM's pilot plant which is produced from crude palm oil (CPO). Every biodiesel blend (B5) samples was stored in storage containers which are made of plastic and insulated glass. B5 refers to 5\% biodiesel and 95\% diesel fuel. In order to vary the storage environment, both plastic and insulated glass storage containers with biodiesel (B5) was kept in three different conditions which are indoor exposed to fluorescent light, indoor without exposed to any form of light and outdoor conditions. In indoor exposed to fluorescent light condition, biodiesel blend was kept inside a room away from any direct sun light except light from a fluorescent light while biodiesel blend which was stored in indoor without exposed to any light condition was kept inside a box whereby exposure to any light will be reduced to the minimum level possible. As for the outdoor condition, it faced natural environment condition and weather changes such as rain, night and sun light. During the first day of experiment, the initial properties condition of each sample was tested in order to be used as a reference for future test.

\section{Experimental Setup}

In this study, under B5 the diesel and biodiesel are blended at a ratio of $95 \mathrm{vol} \%$ and $5 \mathrm{vol} \%$, respectively. In the process of producing biodiesel blend, there are steps which needs to be taken considerably as any mistake might cause the quality of the blend to defer from expected. Besides, the incorrect temperature and stir mode will also cause the biodiesel and diesel to not mix well. After blending process was done, biodiesel blend was stored in 6 different bottles where three of them are made of glass material and the other three are made of plastic material. One glass container and one plastic container were considered as a pair. For the three conditions, which are indoor exposed to fluorescent light, indoor without exposed to any form of light and outdoor, were each placed with one pair of containers filled with biodiesel blend B5. The initial properties condition of each sample was tested in order to be used as a reference for future test. These samples will be stored for twelve weeks and properties tests were done in weekly basis. The properties tests were performed are density, viscosity, acid value, water content and flash point.

\begin{tabular}{|l|l|l|}
\hline Parts Number & Component & Function \\
\hline 1 & Diesel Tank & $\begin{array}{l}\text { Storage andlevel the } \\
\text { diesel }\end{array}$ \\
\hline 2 & Motor & Transmit motion to stir \\
\hline 3 & Biodiesel Tank & $\begin{array}{l}\text { Storage and level the } \\
\text { biodiesel }\end{array}$ \\
\hline 4 & Stir & $\begin{array}{l}\text { Stir the mixture diesel } \\
\text { and biodiesel }\end{array}$ \\
\hline 5 & Supporter & Support the device \\
\hline 6 & Water Inlet Pipe & $\begin{array}{l}\text { Use to inlet water at } \\
\text { the aroundtank }\end{array}$ \\
\hline 7 & $\begin{array}{l}\text { Water and Mixture } \\
\text { Outlet Pipe }\end{array}$ & $\begin{array}{l}\text { To take out the } \\
\text { mixture and water }\end{array}$ \\
\hline 8 & Mixture Tank & $\begin{array}{l}\text { Mixture diesel and } \\
\text { biodiesel }\end{array}$ \\
\hline 9 & Switch Box & $\begin{array}{l}\text { On the device and set } \\
\text { the temperature }\end{array}$ \\
\hline
\end{tabular}

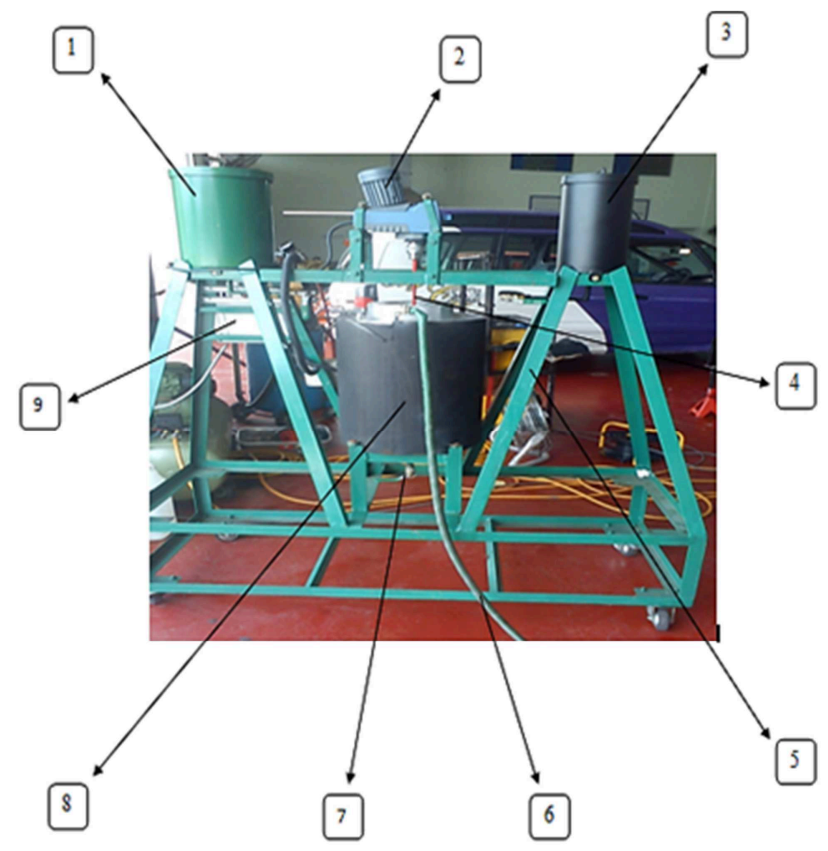

Figure 1 : Blending Machine

In order to produce biodiesel blend and carry out the biodiesel blend properties tests, there are apparatus and chemical solution needed to facilitate the experiments. The apparatus needed are 
burette, beaker, conical flask, graduated cylinder, retort stand, viscometer, volumetric flask, pycnometer, water content analyzer, weighing machine, syringe, heater and refrigerator. As for the chemical solution needed are sodium hydroxide $(\mathrm{NaOH})$, phenolphatale in indicator, 2-propanol, coulomat $\mathrm{AG}$ and coulomat $\mathrm{CG}$. Blending process was required to ensure that the mixture of diesel and biodiesel is well mixed uniformly. This diesel and biodiesel was blended at a ratio of 95:5. The biodiesel was obtained from the UTHM's biodiesel pilot plant while the diesel fuel was bought from a nearby petrol station. The blending process was done using the blending machine at Automotive Laboratory as shown in Figure 1 which includes the component name and function. This blending machine has a maximum capacity of 8 liter and minimum capacity of 5 liter due to the height of stirrer which is positioned quite high from the base. In the blending process the surrounding compartment of the blending machine was filled up with water and was heated up by using the heater until the outer temperature of the blender is $70^{\circ} \mathrm{C}$ while the inner temperature is $60^{\circ} \mathrm{C}$. In addition, $250 \mathrm{ml}$ of biodiesel and $4750 \mathrm{ml}$ of diesel fuel was measured by using a graduated beaker. When the inner temperature had reached $60^{\circ} \mathrm{C}$, the heater was set at $60^{\circ} \mathrm{C}$ in order to maintain the temperature while the measured biodiesel and diesel fuel were poured into the blending machine. The stirrer was switched on while maintaining at a speed of $270 \mathrm{rpm}$. Blending machine was left running for 1 hour before it was done.

\section{Storage Condition}

The sample of biodiesel was taken from UTHM's pilot plant which is produced from crude palm oil (CPO). Every biodiesel blend (B5) samples was stored in storage containers which are made of plastic and insulated glass. B5 refers to $5 \%$ biodiesel and $95 \%$ diesel fuel. In order to vary the storage environment, both plastic and insulated glass storage containers with biodiesel (B5) was kept in three different conditions as shown in Table 1.

Table 1: The Different Condition of Each Sample

\begin{tabular}{|c|c|l|}
\hline Sample & Type of Container & \multicolumn{1}{|c|}{ Condition } \\
\hline $\begin{array}{c}\text { Indoor } \\
\text { exposed to } \\
\text { fluorescent } \\
\text { light }\end{array}$ & Glass & $\begin{array}{l}\text { Biodiesel blend was kept inside a room away from } \\
\text { any direct sun light except light from a fluorescent } \\
\text { light }\end{array}$ \\
\cline { 2 - 3 } $\begin{array}{c}\text { Indoor } \\
\text { without } \\
\text { exposed to } \\
\text { any form of } \\
\text { light }\end{array}$ & Plastic & $\begin{array}{l}\text { Biodiesel blend was kept inside a room away from } \\
\text { any direct sun light except light from a fluorescent } \\
\text { light }\end{array}$ \\
\cline { 2 - 4 } & Plastic & $\begin{array}{l}\text { Biodiesel blend was kept inside a box whereby } \\
\text { exposure to any form of light was reduced to the } \\
\text { minimum level possible. }\end{array}$ \\
\hline \multirow{2}{*}{\begin{tabular}{c} 
Outdoor \\
\cline { 2 - 4 }
\end{tabular}} & $\begin{array}{l}\text { Biodiesel blend was kept inside a box whereby } \\
\text { exposure to any form of light was reduced to the } \\
\text { minimum level possible. }\end{array}$ \\
\cline { 2 - 4 } & Plastic & $\begin{array}{l}\text { Biodiesel blend would face natural environment } \\
\text { condition and weather changes such as rain, night and } \\
\text { sun light }\end{array}$ \\
\hline $\begin{array}{l}\text { Biodiesel blend would face natural environment } \\
\text { condition and weather changes such as rain, night and } \\
\text { sun light }\end{array}$ \\
\hline
\end{tabular}

All the samples were tested in weekly basis for 12 weeks. The properties tests started from the initial week after biodiesel was blended. Among the properties tests took place are viscosity, density, flash point, water content and acid value. The surrounding temperature and humidity were recorded every week as a reference or future use. Besides, there are some factors which have to be remained constant throughout the experiment which includes the biodiesel fuel used for the experiment must be fresh or newly produced so that the result achieved would have higher accuracy. Besides, for the storage condition requirement, all the samples must be placed at the same location before and after testing in order to reduce the side effect resulted by different surrounding 
to the minimum. The quality of biodiesel blend (B5) stored in different storage container material and storage conditions were tested every week for twelve consecutive weeks. The types of properties tests carried out were density, viscosity, acid value, water content and flash point.

\section{Experimental Results}

The experimental results of properties tests which are density, viscosity, flash point, water content and acid value would be discussed. The duration of storage was 12 weeks and the tests were conducted based on weekly basis. All the experiment data were obtained and recorded based on the experiment conducted. In order for a better understanding and to differentiate all the analytical result, all the data were discussed in graphical form. After biodiesel blending process was over, six samples of biodiesel blend were kept in glass and plastic bottles at specified condition for 12 weeks. In between, the sample of biodiesel was tested in terms of density, viscosity, flash point, water content and acid value in weekly basis. During the first day of experiment, the initial properties condition of each sample was tested in order to be used as a reference for future test.

Figure 2 clearly shown that the increasing the storage duration at plastic and glass container under indoor condition, indoor with exposure to fluorescent light condition and outdoor condition for 12 weeks in total promote more biodiesel acid value, viscosity, flash point, water content, and density especially the higher biodiesel blending ratio B5 at plastic outdoor condition. For all physical properties testing the increasing of blending ratio thus predominantly influenced the increasing of storage duration except the viscosity testing it shown most condition decreasing influences the increasing of fuel storage duration, at which time the storage duration plastic container at outdoor of biodiesel is expected to be strongly influenced by the purified crude palm oil methyl ester.

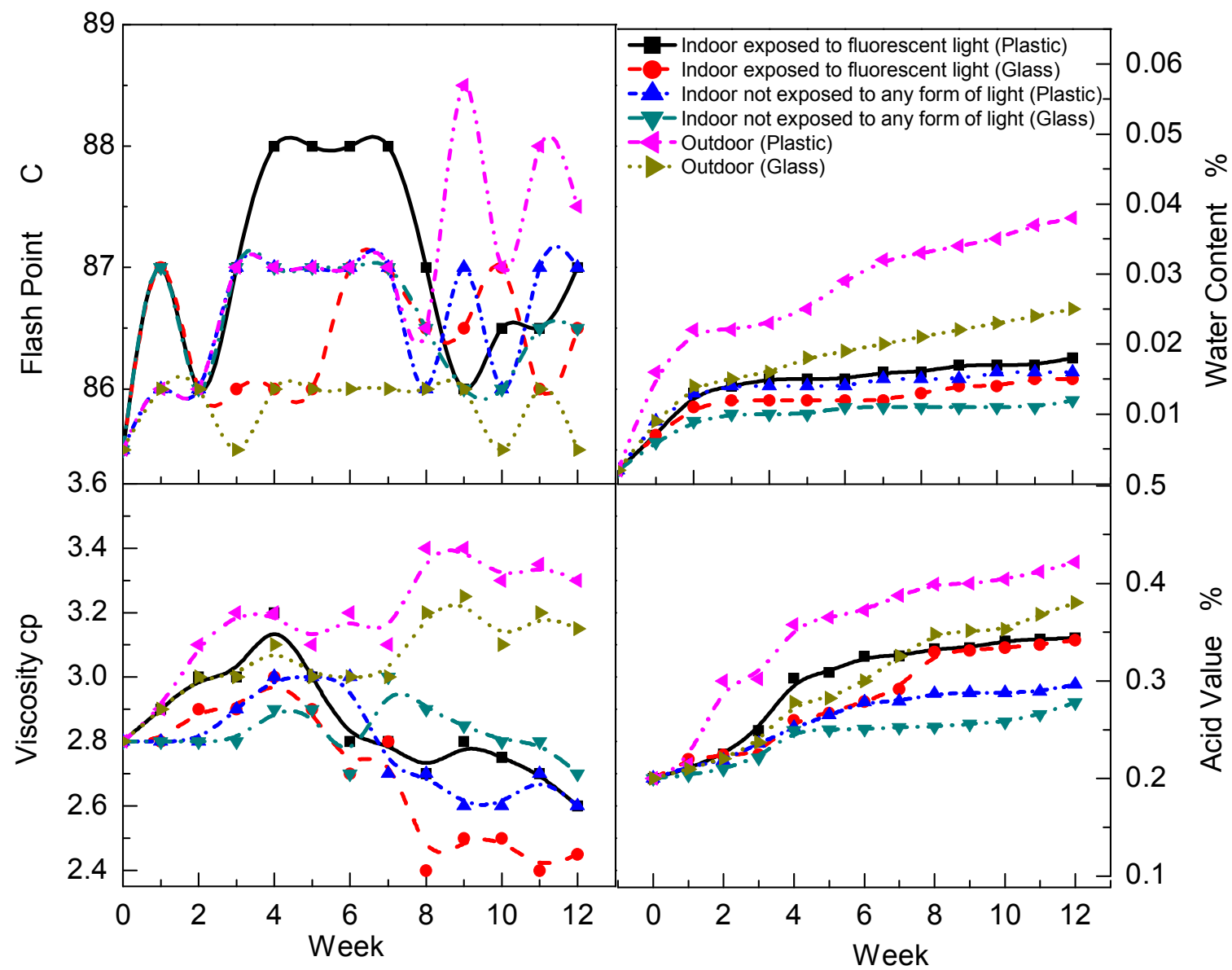

Figure 2: Biodiesel properties storage 


\section{Conclusion}

From the experiment conducted, it showed that there were changes took place among all the properties tests conducted on all the six samples for 8 weeks. Properties which are viscosity, density, acid value and water content were recorded to be in increasing trend while flash point was in decreasing trend. Sample stored in a glass container under indoor without exposed to any form of light condition recorded the best quality while sample stored in a glass container under outdoor condition had the worst quality in terms of flash point, viscosity, density, acid value and water content. These samples were tested to meet the specification of B5 based on ASTM D6751 standard. Flash point, viscosity, density, acid value and water content are among the most important properties which must be tested in order to know if the biodiesel blend is in accordance with the published standard. In conclusion, a long period of storage would decrease the quality of biodiesel no matter what kind of condition and environment is provided. However, the rate of degradation of biodiesel could be slowed down if a proper condition and environment were provided as proven in this experiment. Biodiesel should be stored in a glass container and be kept in an indoor condition without exposure to any form of light.

\section{Acknowledgements}

The authors also would like to thank the Ministry of Higher Education, Malaysia for supporting this research under Research Acculturation Grant Scheme (RAGS) Vot. R025 and Fundamental Research Grant Scheme (FRGS) vot.1054.

\section{References}

[1] Amir Khalid, M.D. Anuar, Yusri Ishak, B. Manshoor, Azwan Sapit, Mutalib Leman, Izzuddin Zaman, "Emissions characteristics of small diesel engine fuelled by waste cooking oil", MATEC Web of Conferences, Volume 13, 2014, Article number 06006, DOI: $10.1051 /$ matecconf/20141306006.

[2] Amir Khalid, Keisuke Hayashi, Yoshiyuki Kidoguchi , Tomoaki Yatsufusa, "Effect of air entrainment and oxygen concentration on endothermic and heat recovery process of diesel ignition", (2011) SAE Technical Papers, DOI: 10.4271/2011-01-1834.

[3] Amir Khalid, N.Tamaldin, M. Jaat, M. F. M. Ali, B. Manshoor, Izzuddin Zaman, "Impacts of biodiesel storage duration on fuel properties and emissions", Procedia Engineering, volume 68, 2013, Pages 225 - 230, Elsevier, 2013, DOI: 10.1016/j.proeng.2013.12.172.

[4] Amir Khalid, Norazwan Azman, Hanis Zakaria, B. Manshoor, Izzuddin Zaman, Azwan Sapit, Mutalib Leman, "Effects of storage duration on biodiesel properties derived from waste cooking oil", Applied Mechanics and Materials, Volume 554, 2014, Pages 494-499, DOI: 10.4028/www.scientific.net/AMM.554.494.

[5] Fazal MA, Haseeb ASMA, Masjuki HH. (2010).Comparative Corrosive Characteristics of Petroleum Diesel and Palm Biodiesel for Automotive Materials. Fuel Process Technol, 91, 1308-15.

[6] Canakci M, Gerpen JV. (1999). Biodiesel Production Via Acid Catalysis. Trans Am SocAgricEng, 42, 1203-10.1.

[7] D.Y.C. Leung, B.C.P. Koo, Y. Guo. (2005). Degradation of Biodiesel under Different Storage Conditions, Bioresource Technology, 251.

[8] Fuzieah Subari. (2010). Pre-Treatment And Alkaline Transesterification Of Used Frying Oil For Biofuel Application, Faculty Of Chemical Engineering, Universiti Teknologi Mara, 2.

[9] Gui MM, Lee KT, Bhatia S. (2008). Feasibility of Edible Oil Vs Non-Edible Oil Vs Waste Edible Oil as Biodiesel Feedstock. J Energy, 33, 1646-53.

[10] Jesus AD, Silva MM, Vale MGR. (2008). The Use of Micro Emulsion for Determination of Sodium and Potassium in Biodiesel by Flame Atomic Absorption Spectrometry.Talanta 74, 1378-84. 